\title{
SIKAP MAHASISWA JURUSAN PENDIDIKAN LUAR BIASA, FAKULTAS ILMU PENDIDIKAN, UNIVERSITAS NEGERI JAKARTA (PLB-FIP, UNJ) TERHADAP PENINGKATAN KETERAMPILAN SOSIALISASI ANAK TUNAGRAHITA MELALUI PENDIDIKAN INKLUSIF
}

\author{
Oleh: Siti Nuraini Purnamawati \\ Email: nuraini@yahoo.com \\ UNIVERSITAS NEGERI JAKARTA
}

\begin{abstract}
This research aims to figure out the position of attitude of undergraduate students of special education programmes, Faculty of Education, State University of Jakarta toward improvement socialisation skills of students with intellectual disabilities through inclusive education. This research used likert scales. The sample of this research was 30. This study used purposive sampled. The reliability of the instrument used Alpha Cronbach is 0.96 compared to $r$ table on $\alpha=0.05$ is 0.63 . Data analysis used planagan formula. Score limit for positive position is $27 \%$ from top's scores and negative position is $27 \%$ from bottom's scores. The highest score is 123 and the smallest score is 89. Score average is 105.16. The result figure out the attitude of undergraduate students in between positive and negative.
\end{abstract}

Keywords: tunagrahita, sosialisasi, pendidikan inklusif

\section{PENDAHULUAN}

Pendidikan inklusif muncul dengan memperhatikan hak azazi manusia dimana pada sekitar tahun 1980 an fakta menunjukkan banyak anak menjadi korban label dan pemisahan. Beberapa siswa di kelas khusus ternyata juga mengalami kesulitan baik dalam bidang akademik maupun dalam kehidupan sosial terutama dengan mereka yang "normal". Nampaknya kegagalan yang dialami dalam pendidikan luar biasa atau pendidikan khusus adalah terkadang menempatkan siswa berkebutuhan khusus yang tidak sesuai dengan kondisi mereka.

Pendidikan inklusif telah dilaksanakan di beberapa negara seperti Australia dan di Selandia Baru. Di Selandia Baru pelaksanaan pendidikan ini nampak dalam UU Pendidikan tahun 1989 pasal 8 yang menyatakan “... people who have special education needs (whether because of disability or otherwise) have the same right to enrol and receive education at state schools as people who do not" (Mitchell, 1995, hal.16).

Di Indonesia istilah inklusif juga kian populer. Istilah ini telah berulang kali masuk ke DPR, dan Direktorat Pendidikan Luar Biasa mulai tahun 2001 mengembangkan pendidikan inklusif menjadi salah satu dari program mereka. Demikian pula dengan Pusat Penelitian Balibangdiknas juga telah mengadakan ujicoba pendidikan inklusif di daerah Wonosari, Gunung Kidul, Yogyakarta.

Pendidikan inklusif berarti memergerkan atau menggabungkan antara pendidikan segregatif dengan pendidikan reguler menjadi suatu pendidikan yang beragam (a unified education). Salah satu kelebihan dilaksanakannya pendidikan inklusif adalah meningkatkan derajat dan persamaan hak semua anak dengan tidak terkecuali. Hal ini didukung oleh deklarasi dunia yang terkenal dengan deklarasi Salamanca, namun ternyata pelaksanaan pendidikan inklusif tidaklah mudah.

Pro dan kontra argumentasi dalam melaksanakan pendidikan inklusif harus dikaji secara mendalam, mengingat yang akan di inklusifkan adalah anak-anak yang memerlukan layanan pendidikan khusus dengan berbagai karakteristik. Berbagai pendapat dan sikap masyarakat baik dari kalangan awam dan akademisipun beragam 
Ketidakmampuan intelektual/tunagrahita adalah salah satu kajian dari pendidikan khusus. Anak-anak yang memiliki ketidakmampuan dalam intelektual adalah termasuk diberi kesempatan untuk mengeyam pendidikan di sekolah regular. Penelitian sebelumnya tentang persepsi siswa regular terhadap siswa dengan ketidakmampuan intelektual ternyata positif. Para siswa tersebut menyambut baik apabila mereka yang tunagrahita belajar bersama di kelas.

Akan tetapi penelitian lain yang telah dilakukan tentang persepsi guru dan kepala sekolah luar biasa dan sekolah regular ternyata berkeberatan apabila siswa dengan ketidakmampuan intelektual ini belajar di sekolah regular, dengan alasan beragam. Untuk melengkapi gambaran tentang penerimaan terhadap siswa dengan ketidakmampuan intelektual atau lebih terkenal dengal istilah tunagrahita di sekolah regular maka penelitian ini akan memfokuskan pada sikap mahasiswa jurusan PLB-FIP UNJ terhadap perkembangan keterampilan sosial anak tunagrahita melalui pendidikan inklusif.

\section{KAJIAN TEORETIS}

Sikap menurut Morgan dkk (1986) adalah ekspresi individual yang merupakan evaluasi dari suatu sikap dari objek tertentu. Evaluasi terhadap objek itu diekspresikan menjadi sesuatu yang berhubungan dengan suka, tidak suka, setuju, tidak setuju, positif atau negatif dan nikmat atau tidak nikmat.

Wortmand dkk (1985) menyatakan bahwa sikap adalah suatu perasaan dekat atau tidak dekat atau pemahaman dengan atau terhadap sekelompok orang tertentu, objek tertentu, ide-ide atau situasi. Sehingga sikap adalah suatu tentang suka atau tidak suka dari perasaan seseorang. Sedangkan menurut Insko dan Scholer (1976) seperti yang dikutip oleh Wortmand dkk (1985) dan Papalia dan Wendkos (1985) sikap adalah suatu konsep yang terdiri dari tiga komponen dasar yaitu (1) kognisi atau kepercayaan tentang seseorang, ide-ide, situasi dan sesuatu, (2) reaksi emosi menuju suatu stimulus dan (3) kecenderungan untuk bertindak.
Dari ketiga batasan di atas terdapat suatu persamaan bahwa sikap adalah sesuatu yang berhubungan dengan suka atau tidak suka, setuju atau tidak terhadap sesuatu tertentu seperti orang, situasi, dan ide. Kesemuanya berdasarkan kepada hasil evaluasi terhadap sesuatu. Lebih dalam lagi, Insko dan Scholer (1976) yang dikutip oleh Wortmand (1985) dan Papalia dan Wendkos (1985) menyatakan sikap terdiri dari kognisi, reaksi emosi dan kecenderungan untuk bertindak. Jadi dapat disimpulkan bahwa sikap adalah suatu kecenderungan untuk bertindak hasil dari evaluasi terhadap suatu objek yang merupakan hasil dari kognisi dan reaksi emosi yang dinyatakan dalam bentuk suka atau tidak suka, setuju atau tidak setuju, positif atau negatif dan nikmat atau tidak nikmat.

Sikap menurut Papalia dan Wendkos (1985) adalah dipelajari. Hal ini sesuai dengan teori belajar yaitu belajar sikap sama seperti belajar yang lain. Ketika belajar suatu informasi yang baru maka kita belajar tentang berbagai perasaan, berbagai pikiran dan berbagai reaksi-reaksi yang berhubungan dengan hal yang dipelajari.

Terbentuknya atau berubahnya sikap adalah akibat dari hasil hubungan interpersonal terhadap sesuatu pada suatu periode tertentu. Wortmand dkk (1985) menegaskan bahwa sikap adalah dipelajari, sikap juga berlangsung untuk waktu yang lama dan sikap mendorong kita untuk beraksi membantu untuk membentuk langsung tingkah laku terhadap sesuatu. Prejudis adalah suatu bentuk sikap negatif terhadap sesuatu karena tidak memahami sesuatu.

Jadi dapat disimpulkan bahwa sikap terbentuk karena dipelajari atau karena hasil interaksi terhadap sesuatu. Hasil interaksi membentuk suatu kecenderungan untuk bertingkah laku. Dari beberapa pendapat dapat dinyatakan pula bahwa sikap itu menjadi sesuatu yang cenderung permanen. Sehingga nampaknya untuk mengubah suatu sikap tertentu diperlukan waktu yang lama. Hal ini sesuai dengan ketika suatu sikap pertama terbentuk, diperlukan waktu yang lama, sehingga untuk mengubah menjadi suatu sikap yang berbeda 
maka diperlukan waktu yang lama pula. Apalagi kalau sikap itu sudah bersifat permanen.

Thurstone (1931) seperti yang dikutip oleh Muller (1986) menyatakan bahwa “... sikap adalah menyukai atau menolak suatu obyek psikologis" (hal 4). Ini berarti bahwa sikap memiliki obyek psikologis. Hal ini diperkuat oleh pendapat dari Azwar (1995) yang mengutip pendapat dari Breckler, (1984), Kate dan Stgotland, (1959), Rajecki, (1982), Biehm dan Kassin (1990) bahwa sikap adalah suatu reaksi terhadap objek kombinasi dari afektif, konasi) dan kognitif.

Selanjutnya menurut Azwar (1995) yang dimaksud dengan kognitif adalah berisi kepercayaan dari seseorang tentang apa yang berlaku atau benar bagi objek sikap. Namun selanjutnya ia menyatakan bahwa kepercayaan itu kadang kurang akurat akibat dari kurang atau tidak adanya informasi yang benar tentang objek yang dihadapi. Kognisi menurut Chaplin (1993) dinyatakan sebagai suatu konsep umum yang berkenaan dengan pengenalan seperti mengamati, menduga dan menilai serta berfikir.

Sedangkan masalah emosional yang subyektif dari seseorang terhadap suatu obyek dinamakan dengan komponen afeksi (Azwar, 1995). Pandangan dari Rosenberg yang dikutip oleh Azwar (1995) menyatakan hal yang sama tentang afektif yaitu suatu perasaan positif atau negatif dari seseorang terhadap suatu objek.

Komponen lain dari sikap adalah komponen konasi atau perilaku yang berhubungan dengan kecenderungan dalam diri seseorang untuk berperilaku terhadap objek yang dihadapinya (Azwar, 1995). Ini sejalan dengan pendapat dari Chaplin (1993) bahwa konasi adalah salah satu aspek kepribadian yang ditandai dengan tingkah laku yang bertujuan untuk berbuat.

Sikap dinyatakan sesuatu yang berhubungan dengan kecenderungan untuk bertindak. Pernyataan dari sikap adalah setuju atau tidak setuju, suka atau tidak suka, pro atau anti, nikmat atau tidak nikmat.

Sebagai individu yang belajar di perguruan tinggi, maka perkembangan mahasiswa atau usia
18 tahun ke atas, adalah pada tingkatan formal operational menurut Piaget. Pada tahapan ini individu mampu untuk menyatakan suatu alasan tentang outcomes, dapat mempertimbangkan halhal abstrak seperti agama, moral dan alternatif gaya hidup.

Usia mahasiswa dapat dinyatakan pada tahapan Intimacy versus Isolation (young adulthood) dan sebagian pada tahapan Generativity Versus Stagnation (midle adulthood) menurut tahapan Ericson. Pada tahapan Intimacy versus Isolation seorang individu berada pada tahapan dewasa muda. Disini dinyatakan bahwa individu dapat berbagi dengan individu lain atau solidaritas terhadap yang lain. Sedangkan sebaliknya apabila individul tersebut tidak dapat untuk berbagi maka individu tersebut akan memiliki perasaan terisolasi dan kehilangan perasaan kasih sayang. Pada tahapan Generativity versus Stagnation atau pada tahapan dewasa tengah atau belum benar-benar menjadi orang tua, individu akan menghasilkan suatu karya atau ide dapat melalui pekerjaan, selain itu individu dapat memiliki suatu perasaan care terhadap individu lain. Sebaliknya apabila individu itu tidak dapat menghasilkan suatu karya atau ide maka individu itu akan menjadi individu pembosan, stagnan dan kurang memiliki perasaan care terhadap individu lain.

Sebagai mahasiswa jurusan Pendidikan Luar Biasa yang mempelajari tentang anak dan individu berkebutuhan khusus, seharusnya memiliki suatu sikap yang dapat care dan sharing dengan anak berkebutuhan khusus termasuk dengan anak tunagrahita. Karena mahasiswa jurusan PLB lebih mengetahui tentang karakteristik dan layanan kebutuhan serta kekurangan dari anak dan individu berkebutuhan khusus.

Sikap dinyatakan dipelajari dan bersifat permanent. Sikap mahasiswa jurusan PLB terbentuk dari rumah, teman, masyarakat dan jurusan PLB. Faktor-faktor tersebut sangat mempengaruhi sikap mahasiswa jurusan PLB terhadap antara lain sesuatu, seseorang atau ide-ide.

Menurut teori belajar sosial, sesuatu diperoleh melalui observasi dan imitasi dari 
tingkah laku orang lain. Dikaitkan dengan sikap maka sikap mahasiswa terhadap anak tunagrahita diperoleh dari observasi terhadap anak tunagrahita.

Berdasarkan teori sistem ecologi, individu dipengaruhi oleh microsystem, mesosystem, exosystem dan macrosystem. Berarti sikap dari mahasiswa jurusan PLB juga dapat dipengaruhi oleh faktor-faktor tersebut. Untuk lebih jelas dapat dilihat dalam gambar di bawah ini:

\section{Gambar 1: Faktor-Faktor yang Mempengaruhi terbentuknya sikap menurut teori Ecologi:}

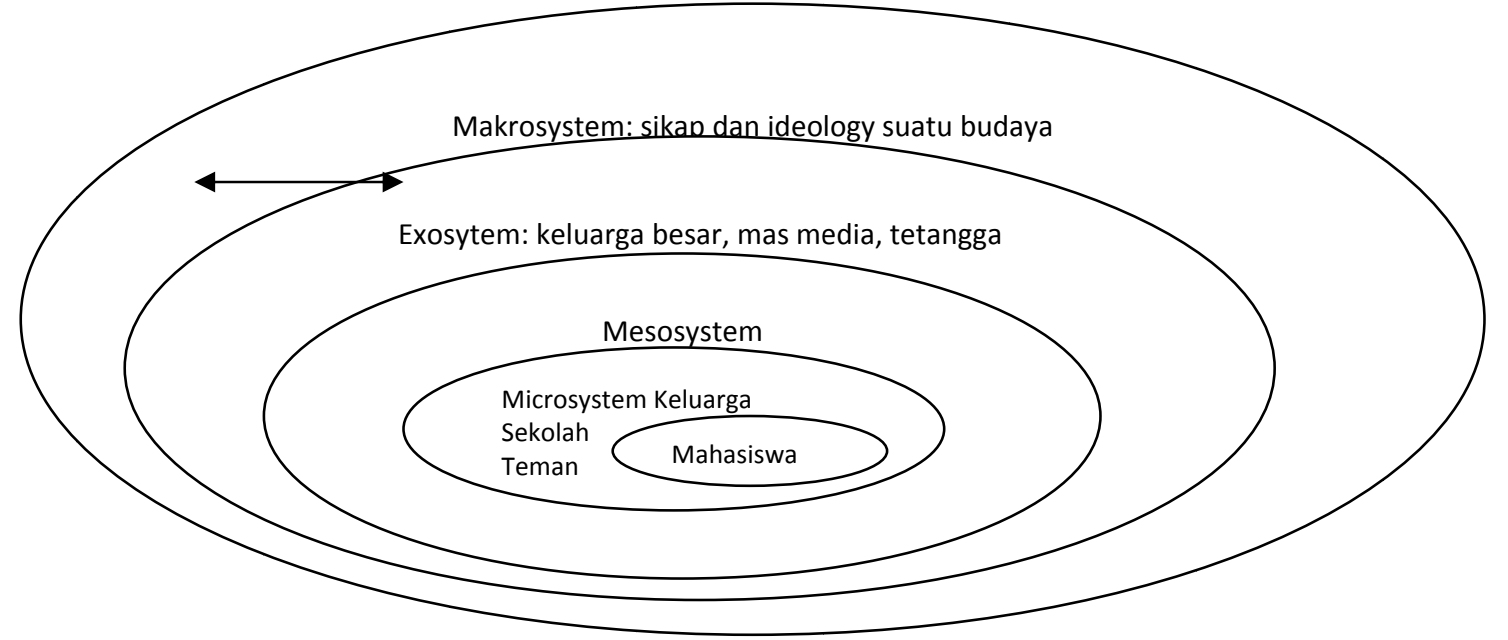

Dari beberapa pendapat di atas dinyatakan bahwa sikap memiliki tiga komponen yaitu kognitif, afektif dan konasi. Hal ini berarti apabila seseorang akan melihat sikap dari seseorang atau kelompok maka haruslah melihat dari ketiga komponen tersebut. Lebih lengkap dapat dilihat pada gambar di bawah ini:

\section{Gambar 2: Konsep mengenali sikap}

Variabel

Independent

Yang dapat diukur

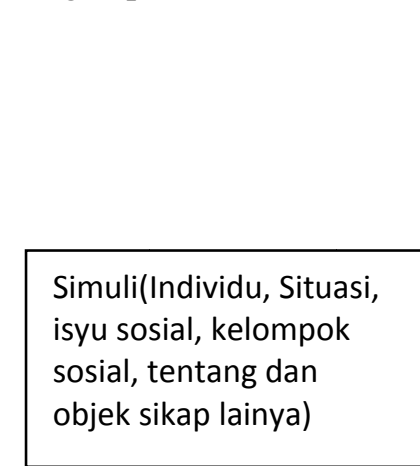

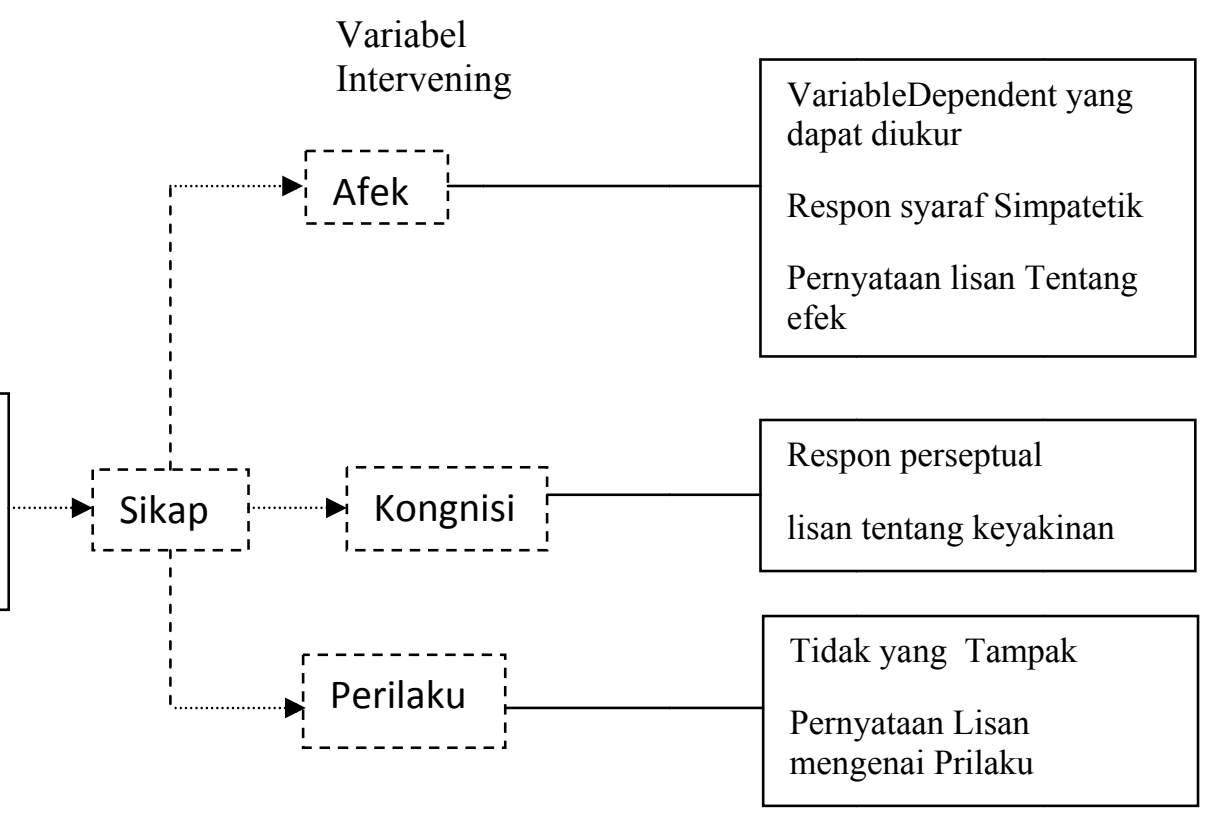

Dikutip dari Azwar (1995) hal 8.

(Konsepsi skematik Rosenberg dan Howland mengenali sikap (diadaptasi dari Fishbein \& Ajzen, 1975, hal. 340) 


\section{Deskripsi Sosialisasi}

Sosialisasi menurut Freud, diartikan sebagai suatu proses yang terus berlangsung dimana anak secara natural bererotik dan berinstink agresif yang secara perlahan-lahan dibawa kebawah kontrol dari superego. Selanjutnya sosialisasi dipengaruhi oleh kepribadian pola asuh orangtua, keluarga, budaya dan nilai-nilai yang ada di masyarakat. Demikian pula dengan Henslin (1999) menyatakan bahwa masyarakat dan kelompok-kelompok sebagai agen-agen dari sosialisasi mempengaruhi konsep diri, emosi, sikap dan tingkah laku dari seseorang.

Menurut Gursec (1985), tujuan utama dari sosialisasi adalah untuk memberi dampak kepada anak-anak untuk berubah dari berpusat pada dirinya kepada minat ke orang lain. Selama bersosialisasi manusia belajar bahasa dari budaya, belajar berbagai peranan pekerjaan dimana manusia sering mengadopsi norma-norma budaya ketika belajar bersosial.

Selain itu ada yang berpendapat bahwa sosialisasi adalah suatu proses dimana manusia belajar untuk memiliki tingkah laku sosial yang baik. Selanjutnya dinyatakan pula bahwa sosialisasi adalah suatu istilah yang digunakan untuk suatu proses dimana individu belajar dan membentuk suatu tingkah laku yang diharapkan oleh masyarakat.

Menurut Charon, (1987) sosialisasi adalah suatu yang esensial yaitu belajar. Sehingga sosialisasi merujuk pada semua yang dipelajari oleh setiap individu pada semua tingkatan usia. Dalam pandangan psychodynamic tradisional sosialisasi berarti suatu saat yang paling penting yang terjadi antara usia satu tahun sampai dengan sepuluh tahun.

Kalangan sosiologis membedakan enam macam sosialisasi yaitu (1) reverse socialisation (sosialisasi keterbalikan), (2) development socialisation (perkembangan sosialisasi), (3) primary socialisation (sosialisasi utama), (4) secondary socialisadion (sosialisasi kedua) (5) anticipatory socialisation (sosialisasi antisipasi) dan (6) resocialisation (mensosialisasikan kembali). Reverse socialisation adalah suatu penyimpangan dari tingkah laku yang diharapkan biasanya dilakukan oleh anak-anak muda. Sedangkan development socialisation adalah proses belajar dalam lembaga sosial, mengembangkan keterampilan sosial. Primary socialisation adalah suatu proses dimana manusia belajar tentang sikap, nilai-nilai dan tingkah laku yang sesuai kepada manusia lain, masyarakat dari suatu budaya tertentu. Selanjutnya secondary socialisation adalah suatu proses belajar tentang apa itu tingkah laku yang baik sebagai anggota dari suatu kelompok kecil dalam suatu kelompok masyarakat besar. Anticipatory socialisation merujuk pada suatu proses sosialisasi dimana seseorang berlatih untuk berbagai posisi dimasa depan, berbagai pekerjaan dan berbagai hubungan sosial. Resocialisation adalah suatu proses membuang suatu pola tingkah laku dan menerima suatu tingkah laku baru sebagai suatu transisi dalam kehidupan seseorang.

Berdasarkan ke enam macam sosialisasi maka dapat dinyatakan bahwa kebiasaan, ide-ide, sikap dan nilai-nilai dikembangkan melalui proses sosialisasi. Selain itu tergambarkan bahwa sosialisasi terjadi apabila seseorang di beritahu apa yang harus dikerjakan dan bagaimana bertingkah laku. Pada umumnya sosialisasi diperlajari secara tidak langsung ketika bersama dengan orang lain. Sehingga dapat disimpulkan bahwa sosialisasi adalah suatu proses belajar tentang suatu pengetahuan, pemahaman, sikap dan tingkah laku yang berlangsung secara terus menerus. Proses sosialisasi yang terbaik adalah pada usia satu sampai sepuluh tahun.

Dalam Detail Definition of Social Compentence dinyatakan bahwa kompetensi sosial adalah memiliki dan menggunakan kemampuan untuk mengintegrasikan berpikir, merasakan dan bertingkah laku untuk meningkatkan tugas-tugas sosial dan nilai-nilai dalam suatu konteks dan budaya. Selanjutnya dinyatakan bahwa kompetensi sosial adalah satu set komponen keterampilan atau prosedur yang diaplikasikan sesuai dengan kondisi. 
Dari pernyataan di atas dapat disimpulkan bahwa kompetensi sosial bermakna sama dengan satu set keterampilan sosial. Kompetensi sosial digunakan untuk berpikir, merasa dan bertingkah laku sesuai dengan kondisi.

Menurut teori intelegensi sosial, terdapat lima kategori dasar keterampilan sosial yaitu (1) kesadaran akan situasi (social/situasional awareness), (2) keberadaan (presence), (3) keaslian (authenticity), (4) kejelasan (clarity) dan (5) empati (empathy). Keterampilan kesadaran akan situasi adalah suatu kemampuan untuk memperhatikan dan memahami kontek pada suatu situasi. Sedangkan keterampilan dalam keberadaan merujuk pada ketertarikan atau keseluruhan pesan yang dikirim dari seseorang kepada orang lain melalui tingkah lakunya. Keterampilan keaslian atau otentik adalah perluasan daripada orang lain menerima seseorang atas kejujuran tingkah laku yang diperlihatkan, dorongan etika, dan perasaan orang lain terhadap seseorang yang bertingkah laku tersebut yang sejalan dengan nilai-nilai personal dari orang itu. Keterampilan kejelasan adalah kemampuan dalam mengekspresikan ide-ide secara jelas, efektif dan berdampak.

Hal ini berhubungan dengan keterlibatan keterampilan berkomunikasi seperti mendengarkan, memberikan umpan balik, paraphrasing, ketidak kakuan dalam sematik, penggunaan bahasa, bermetaforsa dan menggambarkan pembicaraan serta kemampuan dalam menjelaskan sesuatu secara jelas dan tepat. Sedangkan keterampilan empati adalah suatu keterampilan dalam membangun suatu hubungan dengan orang lain.

Sosialisasi dinyatakan dengan suatu proses belajar tentang suatu pengetahuan, pemahaman, sikap dan tingkah laku yang berlangsung secara terus menerus. Proses sosialisasi yang terbaik adalah pada usia satu sampai sepuluh tahun.

Sehingga keterampilan sosialisasi adalah suatu kemampuan khusus yang merupakan suatu proses belajar tentang pengetahuan, pemahaman, sikap dan bertingkah laku dalam berinteraksi dan berhubungan dengan orang lain yang melibatkan kesadaran akan situasional, keberadaan seseorang dalam suatu lingkup tertentu, keaslian seseorang dalam bertingkah laku, kejelasan seseorang dalam memberikan penjelasan terhadap orang orang lain dan perasaan empati dalam kaitannya dengan membangun suatu hubungan dengan orang lain.

Keterampilan sosialisasi terdiri dari enam macam yaitu keterampilan sosialisasi keterbalikan atau memiliki suatu tingkah laku yang berbeda dengan masyarakat, keterampilan sosialisasi yang dibelajarkan pada lembaga sosial, keterampilan sosialisasi yang sesuai dengan nilai-nilai masyarakat tertentu, keterampilan sosialisasi dalam bertingkah laku yang sesuai dengan masyarakat kecil yang merupakan bagian dari masyarakat besar, keterampilan sosialisasi dalam mengantisipasi masa depan seperti pada bidang pekerjaan dan posisi, dan keterampilan sosialisasi dalam membuang tingkah laku yang telah dimiliki untuk memiliki suatu tingkah laku baru.

\section{Deskripsi Tunagrahita}

Berbagai istilah telah digunakan untuk menjelaskan tentang tunagrahita. Anak dengan ketidakmampuan intelektual atau anak dengan hambatan intelektual adalah istilah yang ada sekarang. Dimasa lalu tidak ada perbedaan antara mereka yang tidak mampu dalam intelektual dengan penyakit mental, perbedaan di mulai pada pertengahan abad (the American Association on Mental Defficiency, di kutip dari Grossman, 1983).

Coleman (1980) memandang ketidak mampuan intelektual sebagai intelektual pendek yang diukur oleh tes intelegensi. Orsten dan Carstensen (1991) menyatakan bahwa ketidak mampuan intelektual sebagai kerusakan dalam fungsi intelektual dan penyesuaian tingkah laku. Menurut Goldberg, Benjamin dan Creed (1994) ketidak mampuan intelektual merujuk pada gangguan dalam perkembangan yang berakibat pada intelegensi dan juga menuju pada kerusakan dari fungsi sosial. Sedangkan Hayes dan Hayes (1982) dan Warren (1987) menggunakan batasan yang digunakan oleh the American Association on Mental Defficiency (AAMD) tahun 1983 yaitu: 
retardasi mental merujuk pada secara signifikan fungsi intelektual umumnya dibawah rata-rata, terlihat adanya kekurangan dalam adaptasi tingkah laku dan manifestasinya selama periode perkembangan.

Istilah Intellectual disability adalah istilah yang digunakan oleh American Association on Intellectual and Developmental Disabilities (AAIDD) (2017) yang didefinisikan sebagai “ $\ldots a$ disability characterized by significant limitations in both intellectual functioning and in adaptive behavior, which covers many everyday social and practical skills. This disability originates before the age of 18" (halmn.1)

Dari batasan ini terlihat bahwa untuk menunjukkan bahwa seseorang itu memiliki ketidak mampuan intelektual harus ada tiga hal yang penting yaitu fungsi intelektual di bawah ratarata, keterbatasan dalam keterampilan beradaptasi dan manifestasinya sebelum usia 18 tahun atau pada periode perkembangan.

Menurut American Association on Intellectual and Developmental Disabilities (AAIDD) (2017) “... intellectual functioning also called intelligence-refers to general mental capacity, such as learning, reasoning, problem solving, and so on. One way to measure intellectual functioning is an IQ test. Generally, an IQ test score of around 70 or as high as 75 indicates a limitation in intellectual functioning" (halmn.1)

Sedangkan untuk adaptasi perilaku didefinisikan sebagai "...the collection of conceptual, social, and practical skills that are learned and performed by people in their everyday lives" (.halmn.1)

Menurut Drew dan kawan-kawan (1990), mereka yang tergolong ringan dapat bersekolah di sekolah umum dan mendapatkan keuntungan dari system tersebut seperti kurikulum yang sama dengan modifikasi berdasarkan kebutuhan mereka. Hal ini ditopang oleh deklarasi dunia tentang pendidikan untuk semua yaitu:
1. Every person - child, youth and adult, shall be able to benefit from educational opportunities designed to meet their basic learning needs.

2. The learning needs of the disabled demand special attention. Steps need to be taken to provide equal access to education to every category of disabled person as an integral part of the education system (Mitchell, 1994, hal.3).

Selanjutnya dalam dokumen Salamanca (1994) dinyatakan bahwa:

1. Every child has a fundamental right to education, and must be given the opportunity to achieve and manintain an acceptable level of learning,

2. Every child has unique characteristics, interests, abilities and learning needs. Education systems should be designed and educational programmes implemented to take into account the wide diversity of these characteristics and needs,

3. Those with special educational needs must have access to reguler schools which should accomodate them within a childcentred pedagogy capable of meeting these needs. (halviii).

Hal ini terlihat bahwa semua anak termasuk anak-anak dengan kebutuhan khusus berhak mempunyai akses mendapatkan pendidikan pada lembaga-lembaga pendidikan reguler.

Pendidikan inklusif yang menjadi suatu isu adalah ".. the merger of special and regular education into a unified education system" (Andrew dkk, 1993, hal.5), dengan kata lain penyatuan pendidikan khusus dan pendidikan reguler menjadi suatu sistem pendidikan yang beragam.

Sunardi seperti yang dikutip oleh Sunardi (2002) menyatakan bahwa inklusif sampai saat ini masih diperdebatkan di beberapa negara barat. Para pendukung konsep pendidikan inklusif beragumen antara lain: belum banyak bukti empiris yang mendukung asumsi bahwa layanan pendidikan khusus yang diberikan di luar kelas biasa 
menunjukkan hasil yang lebih positip bagi anak, biaya pendidikan luar biasa yang relatif lebih mahal daripada biaya pendidikan umum. pendidikan di luar kelas biasa mengharuskan penggunaan label luar biasa yang dapat berakibat negatif bagi anak. banyak anak luar biasa yang tidak mampu memperoleh layanan pendidikan karena tidak tersedia di sekolah terdekat dan anak luar biasa harus dibiasakan tinggal dalam masyarakat bersama warga masyarakat lainnya.

Membangun asmosfir inklusif menurut Lang dan Berberich (1995) adalah dari suatu rentangan yang luas dari hubungan antara masyarakat dan berbagai pertimbangan yang semuanya dipengaruhi dari berbagai pengalaman, kepercayaan, dan sikap, yang dapat digambarkan sebagai berikut:

\section{Gambar 3: Pembangunan Atmosfir Inklusif}

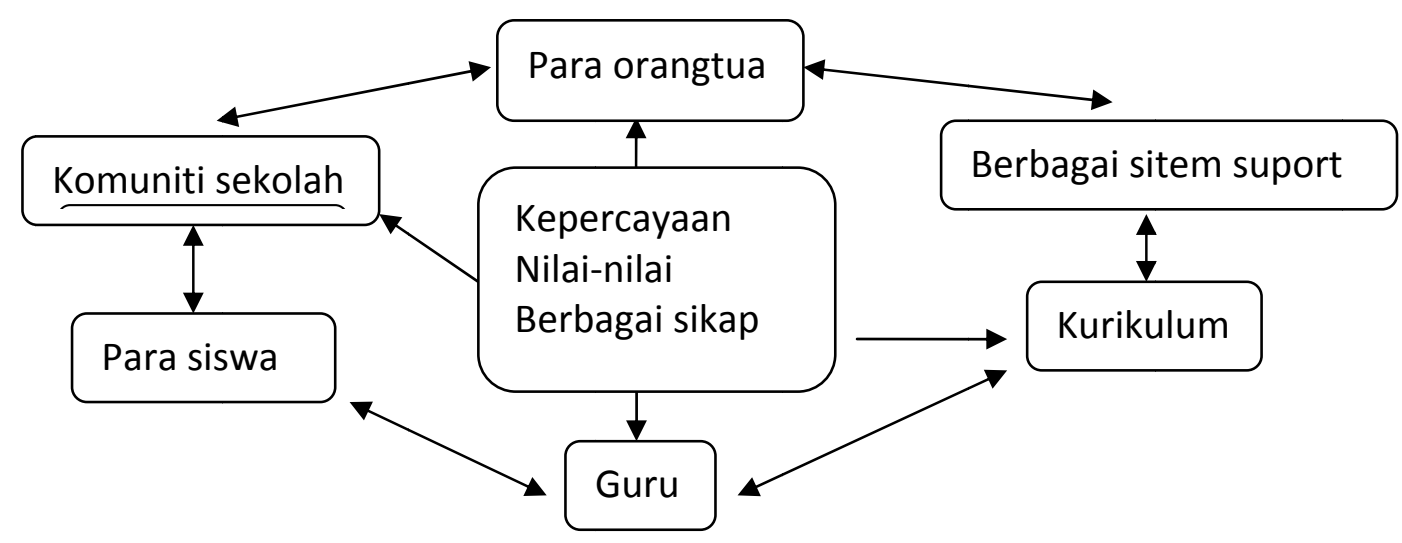

(Lang dan Berberich, 1995, hal.24)

Kesuksesan dari pendidikan inklusif berdasarkan kerangka di atas adalah berdasarkan keterkaitan antara kepercayaan, nilai-nilai dan sikap-sikap dari semua elemen yaitu para orangtua, para guru, sistem-sistem yang mendukung, kurikulum, para siswa dan komunitas sekolah. Kesemuanya merupakan suatu ikatan yang kuat untuk membangun kesuksesan dari layanan ini.

Sedangkan core dari inklusi dapat dilihat pada gambar di bawah ini:

\section{Gambar 4: Core Inklusif}

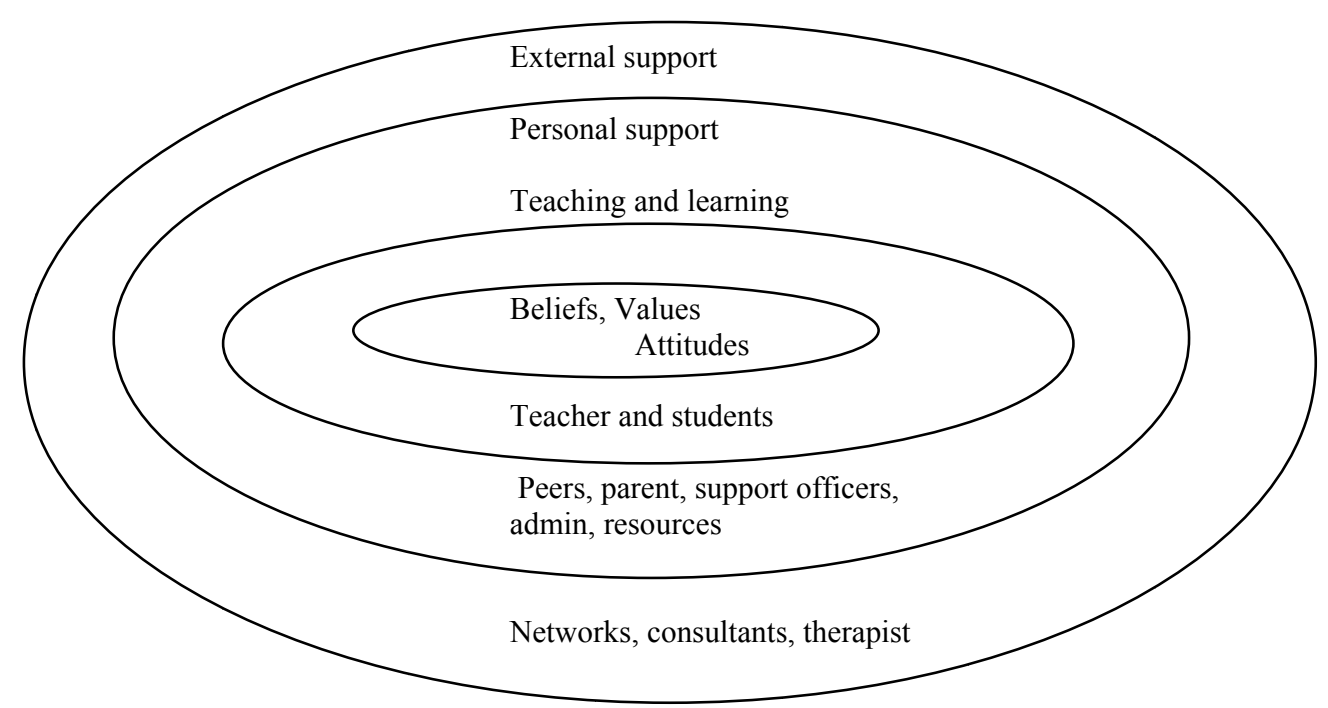

(Lang dan Berberich, 1995, hal.25). 
Bagan di atas menunjukkan bahwa elemen utama dari kesuksesan proses inklusi adalah pada guru. Dalam bagan ini anak-anak dengan kebutuhan khusus berada di lingkungan yang sama dengan anak-anak lain dan guru. Disini anak-anak mendapatkan kesempatan belajar yang sama.

Keunggulan dan berbagai pertimbangan dalam pelaksanaan pendidikan inklusif harus dicermati apabila pendidikan inklusif akan dilaksanakan di Indonesia. Keunggulan dalam penerapan di satu negara mungkin tidak menjadi ungul di negara lain karena faktor seperti budaya dan tingkat pendidikan dari suatu negara. Giorcelli (1993) mencatat beberapa beberapa keunggulan yang dirasakan oleh beberapa orang tua dan penasehat tentang pelaksanaan pendidikan inklusif di New South Wales, Australia antara lain: (1) pelaksanaan pendidikan inklusif memberikan dampak pada pada siswa yang tidak memiliki kebutuhan khusus karena mereka lebih mentolerir keadaan siswa yang memiliki kebutuhan khusus, (2) memberikan kesempatan pada semua siswa baik yang memiliki dan tidak memiliki kebutuhan khusus untuk membangun suatu pertemanan, (3) mengembangkan kolaborasi dalam mengajar dan konsultasi diantara sekolah-sekolah regular dan para ahli dan (4) mengurangi hambatan pembelajaran yang biasa terjadi pada siswa yang memiliki kebutuhan khusus. Namun terdapat beberapa pertimbangan lain apabila pendidikan inklusif ini harus dilaksanakan pada semua wilayah antara lain: (1) kebutuhan akan pengembangan staf yang akan memakan banyak biaya dan (2) kebutuhan akan proses strukturisasi yang diberlakukan dalam persiapan sekolah inklusif.

Pendidikan inklusif ternyata tidak membawa kekhawatiran pada beberapa masyarakat, hal ini dikemukakan oleh Staub dan Peck tahun 1994 seperti yang dikutip oleh Sunardi (2000) yaitu (1) perkembangan akademik siswa yang 'normal' tidak terhambat oleh kehadiran siswa yang memiliki kebutuhan khusus di kelas mereka, (2) guru tidak dirugikan dengan keberadaan siswa berkebutuhan khusus di kelas mereka, (3) siswa yang 'normal' tidak meniru/tertular oleh perilaku menyimpang dari siswa dengan kebutuhan khusus. Selain itu Staub dan Peck (1994/1995) seperti yang dikutip pula oleh Sunardi (2000) menyatakan ada lima kelebihan yang diperoleh dari pelaksanaan pendidikan inklusif yaitu: (1) berkurangnya rasa takut akan perbedaa individual dan semakin besarnya rasa percaya dan peduli pada siswa berkebutuhan khusus, (2) pertumbuhan kognisi sosial yang berarti siswa-siswa yang 'normal' semakin toleran pada orang lain setelah mereka memahami kebutuhan temannya yang memiliki kebutuhan khusus, (3) peningkatan konsep diri pada siswa-siswa yang 'normal', (4) menumbuhkan prinsip-prinsip pribadi pada siswa-siswa yang 'normal' dan (5) terbentuknya persahabatan yang erat dan penuh perhatian antara siswa-siswa yang 'normal' dengan siswa-siswa yang memiliki kebutuhan khusus.

Dapat disimpulkan bahwa pendidikan bagi mereka dengan gangguan intelektual ringan atau tunagrahita ringan dapat dilakukan pada satuan pendidikan umum.

\section{METODOLOGI PENELITIAN}

Penelitian ini bertujuan untuk memperoleh informasi tentang sikap para mahasiswa jurusan PLB FIP UNJ terhadap perkembangan keterampilan sosial anak tunagrahita melalui pendidikan inklusif. Variabel penelitian ini hanya ada satu sikap mahasiswa jurusan PLB FIP UNJ.

Definisi Konseptual Sikap mahasiswa adalah suatu kecenderungan untuk beraksi secara lisan atau perilaku hasil dari evaluasi terhadap suatu objek melalui panca indera yang dinyatakan dalam bentuk suka atau tidak suka, setuju atau tidak setuju, positif atau negatif dan nikmat atau tidak nikmat. Definisi Operasional Sikap mahasiswa adalah skor mengenai kecenderungan untuk beraksi terhadap keterampilan sosialisasi anak tunagrahita melalui pendidikan inklusif yang mencakup aspek: (1) bergaul, (2) komunikasi dan (3) kerjasama. 
Dalam penelitian ini digunakan instrumen berupa angket tertutup dengan skala likert untuk para mahasiswa jurusan PLB FIP UNJ yang terdiri dari sangat setuju, setuju, ragu-ragu, tidak setuju, dan sangat tidak setuju. Penilaian dalam skala ini adalah sangat setuju $=5$, setuju $=4$, ragu-ragu $=3$, tidak setuju $=2$ dan sangat tidak setuju $=1$ untuk pernyataan positif. Sedangkan untuk pernyataan negatif adalah sebaliknya yaitu sangat setuju=1, setuju-2, ragu-ragu $=3$, tidak setuju $=2$ dan sangat tidak setuju $=1$. Skala tersebut disusun berdasarkan tiga komponen dari aspek yaitu kognitif, afektif dan konasi atau perilaku. Komponen objek sikap adalah aspek sosialisasi yang terdiri dari bergaul, komunikasi dan bekerjasama.

Populasi penelitian ini adalah para mahasiswa jurusan PLB FIP UNJ Sampel penelitian sejumlah 30 orang. Pemilihan sampel dilakukan dengan purposive sampling. Dalam penyusunan instrumen ini digunakan validitas bangun pengertian. Untuk perhitungan menggunakan rumus Product Moment

$$
\mathrm{r}_{\mathrm{xy}}=\frac{\mathrm{N}\left(\sum \mathrm{xy}\right)-\left(\sum \mathrm{x}\right)\left(\sum \mathrm{y}\right)}{\sqrt{ }\left\{\mathrm{N} \cdot \sum \mathrm{X}^{2}-\left(\sum \mathrm{x}\right)^{2}\right\}\left\{\mathrm{N} \cdot \sum \mathrm{y}^{2}-\left(\sum \mathrm{Y}\right)^{2}\right\}}
$$

\section{Keterangan:}

$\mathrm{r}_{\mathrm{xy}} \quad$ : Angka indeks " $\mathrm{r}$ " product moment

$\mathrm{N}$ : Jumlah sample

¿xy : Jumlah hasil perkalian antara skor $\mathrm{x}$ dan $\mathrm{y}$

$\sum \mathrm{x} \quad$ : Jumlah seluruh skor $\mathrm{x}$

$\sum y \quad$ : Jumlah seluruh skor y

r table pada $\alpha=0.05$ adalah 0.63 . Untuk mengetahui realibilitas instrumen ini, penelitian ini menggunakan rumus Alpha Crombach dan hasilnya adalah 0.96 .

Data yang terkumpul selanjutnya dianalisis dengan menggunakan rumus planagan.

\section{HASIL PENELITIAN}

Dari hasil perhitungan didapat skor keseluruhan terbesar adalah 123 dan skor keseluruhan terkecil adalah 94. Skor rata-rata adalah 105,16 . Skor batas positif adalah $27 \%$ dari batas atas yaitu 8,1 . Skor-skor itu adalah 113, 114, $115,115,117,117,118$ dan 123. Skor batas negative adalah $27 \%$ dari batas bawah yaitu 8,1 . Skor-skor itu adalah 89, 94, 94, 96, 97, 97,9 7 dan 97 pada tabel 1 di bawah ini:

\begin{tabular}{|c|c|}
\hline No & Skor Perolehan \\
\hline 1 & 123 \\
\hline 2 & 118 \\
\hline 3 & 117 \\
\hline 4 & 117 \\
\hline 5 & 115 \\
\hline 6 & 115 \\
\hline 7 & 114 \\
\hline 8 & 113 \\
\hline 9 & 110 \\
\hline 10 & 110 \\
\hline 11 & 109 \\
\hline 12 & 108 \\
\hline 13 & 107 \\
\hline 14 & 107 \\
\hline 15 & 105 \\
\hline 16 & 105 \\
\hline 17 & 102 \\
\hline 18 & 102 \\
\hline 19 & 102 \\
\hline 20 & 101 \\
\hline 21 & 100 \\
\hline 22 & 97 \\
\hline 23 & 97 \\
\hline 24 & 97 \\
\hline 25 & 97 \\
\hline 26 & 96 \\
\hline 27 & 94 \\
\hline 28 & 94 \\
\hline 29 & 94 \\
\hline 30 & 89 \\
\hline
\end{tabular}

\section{Tabel 1 Skor Urutan Data Keseluruhan}


Hasil penelitian juga dapat dilihat pada gambar pie di bawah ini Gambar 5 Sebaran persentasi data

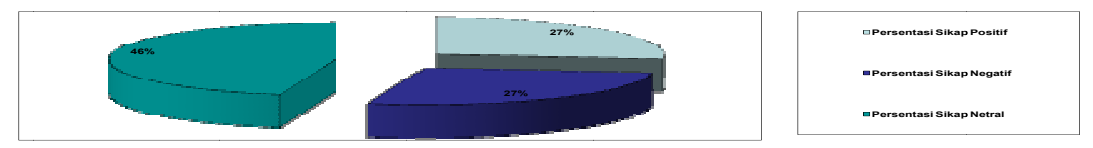

Dari gambar di atas terlihat bahwa belahan sikap yang netral lebih kecil daripada belahan perpaduan antara sikap positif dan negatif. Dalam penelitian ini skor yang diambil adalah skor keseluruhan. Hasil penelitian juga menunjukkan skor rata-rata adalah 105,16. Ini berarti bahwa ratarata sikap mahasiswa Jurusan PLB-FIP UNJ berada pada antara sikap positif dan negatif, karena skor batas bawah adalah dari 89 ke 105, dan skor batas atas adalah 113 ke 123 .

Kalau dilihat dari hasil penelitian maka sikap mahasiswa berada diantara sikap positif dan negatif. Berdasarkan hal ini maka dapat dinyatakan bahwa rata-rata mahasiswa Jurusan PLB-FIP UNJ masih memiliki sikap keraguan terhadap keterampilan sosialisasi pada anak tunagrahita melalui pendidikan inklusif.

Secara teoretik, keterampilan sosialisasi pada anak tunagrahita mengalami hambatan. Sekolah reguler yang menerapkan pendidikan inklusif menyediakan suatu lingkungan yang disengaja untuk anak-anak tunagrahita mengadakan interaksi dengan anak-anak lain baik yang tidak berkebutuhan khusus maupun dengan yang "normal".

Pendidikan inklusif secara teoretik dan praktik menyediakan fasilitas agar anak tunagrahita dapat berimitasi dan beridentifikasi dengan anak "normal". Akibat dari hubungan simbiosis tersebut anak-anak tunagrahita mendapatkan pengetahuan, pemahaman dan menerapkan cara-cara bersosialisasi paling tidak mereka dapat bergaul, berkomunikasi dan bekerjasama, sehingga mereka dapat diterima minimal sebagai anggota masyarakat di sekolah tersebut.

Jurusan PLB FIP UNJ adalah jurusan yang menyediakan kajian-kajian tentang anak/individu berkebutuhan khusus termasuk anak tunagrahita. Semua mahasiswa Jurusan PLB mempelajari semua kajian termasuk menganalisis layanan pendidikan bagi anak berkebutuhan khusus. Layanan pendidikan inklusif telah mereka pelajari baik secara teori maupun observasi melalui film dan lapangan. Untuk itu mereka seharusnya telah memiliki sikap positif terhadap setiap layanan pendidikan bagi anak berkebutuhan khusus.

\section{SIMPULAN, IMPLIKASI DAN SARAN Simpulan}

Berdasarkan hasil penelitian dapat disimpulkan bahwa skor rata-rata sikap mahasiswa jurusan PLB FIP UNJ adalah 105,16. Hal ini menunjukkan bahwa sikap mahasiswa tidak positif dan tidak negatif. Ini menunjukkan bahwa peningkatan keterampilan sosialisasi pada anak tunagrahita melalui pendidikan inklusif masih diragukan oleh mahasiswa Jurusan PLB-FIP UNJ.

\section{Implikasi}

Berdasarkan hasil penemuan bahwa sikap mahasiswa Jurusan PLB-FIP UNJ masih ragu-ragu terhadap peningkatan keterampilan sosialisasi pada anak tunagrahita melalui pendidikan inklusif, maka sikap tersebut harus dirubah melalui peningkatan pembelajaran tentang kajian pendidikan inklusif terhadap anak tunagrahita. 


\section{Saran}

Berkaitan dengan implikasi maka saransaran yang diajukan adalah sebagai berikut:

a. Agar materi pendidikan inklusif tetap diberikan tidak hanya sebagai pengetahuan di kelas tetapi sebagai suatu materi yang terus menerus dikaji dan diteliti melalui pembelajaran yang menyenangkan.

b. Dalam memberikan materi tentang pendidikan inklusif dan tunagrahita sebaiknya pembagian teori, praktik dan lapangan seimbang, sehingga mahasiswa mendapatkan pengalaman langsung.

\section{DAFTAR PUSTAKA}

American Association on Intellectual and Developmental Disabilities (AAIDD), http://aaidd.org/intellectualdisability/definition

Andrew, J., Lupart, J., Bachor, D., Crealock, C., Marling, C.D., Marini, A, and Piper, D. (1993). The Inclusive Classroom, Educating Exceptional

Azwar, Saifudin (1995). Sikap Manusia, Teori Dan Pengukurannya. Edisi ke 2 Yogjakarta: Pustaka Pelajar Offest

Conference on Special Needs Education: Access and Quality. Salamanca, Spain, June 7-10, 1994

Lang, G., and Berberich, C. (1995). All Children are Special. Creating an Inclusive
Classroom. Australia: Eleanor Curtain Publishing.

Mar'at. (1981), Sikap Manusia Perubahan Serta Pengukurannya. Bandung: Ghalia Indonesia

Mitchell, D. (1994). Inclusive Education in Asia: Policies, Problems and Possiblities. Hamilton: University of Waikato, School of Education

Ministry of Education and Science, Madrid (Spain) (1994). The Salamanca Statement and Framework for Action on Special Need Education. Adopted by the World Conference on Special Needs Education: Access and Quality. Salamanca, Spain, June 7-10, 1994

Morgan C.T dkk (1986). Introduction to Psychology, 7th ed, New York: McGrawHill Book Company

Sunardi, (1997.), Kecenderungan Dalam Pendidikan Luar Biasa. Departemen Pendidikan Dan Kebudayaan, Direktorat Jenderal Pendidikan Tinggi, Proyek Pendidikan Tenaga Akademik.

Sunardi, (2002). Pendidikan Inklusif: Prakondisi dan Implikasi Managerialnya. Makalah disampaikan pada Temu Ilmiah PLB Tingkat Nasional, Bandung 6-8 Agustus 2002 